\title{
Extraction and analysis of the parietal polysaccharides of acorn pericarps from Quercus trees
}

\author{
Moubarek Mébarki $^{1^{*}}$ (D), Kadda Hachem ${ }^{1,2}$ (D), Céline Faugeron-Girard ${ }^{3}$ (D), Riad el Houari Mezemaze ${ }^{1}$ and \\ Meriem Kaid-Harche ${ }^{1}$
}

\begin{abstract}
${ }^{1}$ Laboratoire des Productions, Valorisations Végétales et Microbiennes - LP2VM, Faculté des Sciences de la Nature et de la Vie, Université des Sciences et de la Technologie d'Oran Mohamed Boudiaf, Oran, Algérie

${ }^{2}$ Département de Biologie, Faculté des Sciences, Université Dr. Moulay Tahar de Saida, Saida, Algérie ${ }^{3}$ Laboratoire PEIRENE, Faculté des Sciences et Techniques, Université de Limoges, Limoges, France

*moubarek.mebarki@univ-usto.dz
\end{abstract}

\begin{abstract}
Acorns produced by Quercus trees are currently underexploited and undervalued. To evaluate the commercial and health benefits of acorns, we examined the cell wall components of acorn pericarps from Quercus suber and Quercus ilex, growing in North-Western Algeria. Acorn pericarps were sequentially extracted and the polysaccharide fractions were analyzed by gas liquid chromatography and Fourier-transform infrared spectroscopy. The lignocellulosic fraction was the major component of $Q$. suber and $Q$. ilex cell walls (37.19\% and $48.95 \%$, respectively). Lower amounts of pectins and hemicelluloses were also found in both species. Hemicellulose extracts from the two species contained xylose as the major monosaccharide (ranging from $36.7 \%$ to $49.4 \%$ ). Galacturonic acid was the major component of hot water- or ammonium oxalate-extracted pectins from both species (ranging from $20.6 \%$ to $46.8 \%$ ). The results reported in this paper reveal that acorn pericarp cell walls from these two oak could be potential sources of bioactive compounds.
\end{abstract}

Keywords: Quercus sp., pericarp, polysaccharides.

How to cite: Mébarki, M., Hachem, K., Faugeron-Girard, C., Mezemaze, R. H., \& Kaid-Harche, M. (2019). Extraction and analysis of the parietal polysaccharides of acorn pericarps from Quercus trees. Polímeros: Ciencia e Tecnologia, 29(3), e2019044. https://doi.org/10.1590/0104-1428.06119

\section{Introduction}

The genus Quercus spp. is one of the most species-rich genus among forest trees. This genus consists of several hundred species which grow in temperate, as well as in Mediterranean climates, particularly in America, Europe, and Asia $^{[1]}$.

In Algeria, oak trees represent an important forest resource, as they account for nearly $40 \%$ of the Algerian forest, and play important ecological, economic roles. In Algeria the local population uses the fruit of Quercus as a traditional food resource ${ }^{[2]}$. Numerous studies have recently explored the health benefits of natural plant compounds including bioactive compounds such as polyphenols, proteins, lipids, vitamins, polysaccharides, and other constituents ${ }^{[3]}$.

Cell walls are important for the growth and the development of plants; they provide a significant barrier to diseases, making them targets for improving the post-harvest storage and processing of the fruits. Thus, studies evaluating how plants synthesize and remodel their cell walls constitute an important and expanding area of research, particularly in the renewable energy field ${ }^{[4]}$.

Identifying, isolating, and evaluating new sources of bioactive polysaccharides, in order to promote their use in technological applications or food formulations has recently

been widely examined ${ }^{[5]}$. Although a few works have been dedicated to acorns ${ }^{[6]}$, no single study exists which has been specifically devoted to acorn pericarps.

This study was conducted to evaluate the cell wall of acorn pericarps from two Quercus species growing in different regions of North-Western Algeria, in the Saida (high plateau region) and Oran (coastal region) areas. To the best of our knowledge, the present study is the first report on cell wall polysaccharides extracted from acorn pericarps.

\section{Materials and Methods}

\subsection{Plant material}

The two different oak species, Q. suber and Q. ilex, were selected because of their high prevalence among North-Western Algerian forests. Acorn samples, from approximately 100 year old trees, were collected in December 2016, Q. ilex in the Saida region $\left(34^{\circ} 48^{\prime} 45.5^{\prime} \mathrm{N} 0^{\circ} 09^{\prime} 43.5^{\prime} \mathrm{E}\right)$ and $Q$. suber in the Oran region ( $\left.35^{\circ} 38^{\prime} 20.3^{\prime \prime} \mathrm{N} 0^{\circ} 50^{\prime} 22.6^{\prime} \mathrm{W}\right)$ and were identified by Pr. Meriem Kaid Harche. Two voucher specimens (QS 8409 and QI 8410) have been deposited at the Herbarium of the Department of Biotechnology, Mohamed 
Boudiaf University of Sciences and Technology, Oran, Algeria. After cleaning, pericarps were manually detached from acorns and dried in a ventilated oven $\left(40^{\circ} \mathrm{C}\right)$. Pericarps were then ground (particle size $<200 \mu \mathrm{m}$ ), and the resulting powder was stored in desiccators at room temperature.

\subsection{Sequential extraction of parietal components}

The sequential and selective extraction of parietal polysaccharides present in acorn pericarps from $Q$. suber, and Q. ilex, was carried out according to Hachem et al. ${ }^{[7]}$. All extraction procedures were carried out using magnetic stirring. All extracts were filtered through a porous glass frit (Porosity number 3 ) and then transferred to pre-soaked dialysis tubing (Spectra/Por; molecular weight cutoff 6000-8000 Da). After dialysis, polymers were precipitated by addition of 3 volumes of $96 \%$ ethanol, centrifuged, and finally freeze-dried. The subsequent fractionation procedure is summarized in Figure 1.

\subsection{Colorimetric assay of total sugars}

Sugars in the polysaccharide fraction were identified using the sulfuric phenol methodfor neutral sugars with glucose as standard ${ }^{[8]}$, and the meta-hydroxydiphenyl (m-HDP) method for uronic acids with glucuronic acid as standard ${ }^{[9]}$. Because of the interference of uronic acids in the determination of neutral sugars and vice versa, it was necessary to apply the correction method established by Montreuil et al. ${ }^{[10]}$.

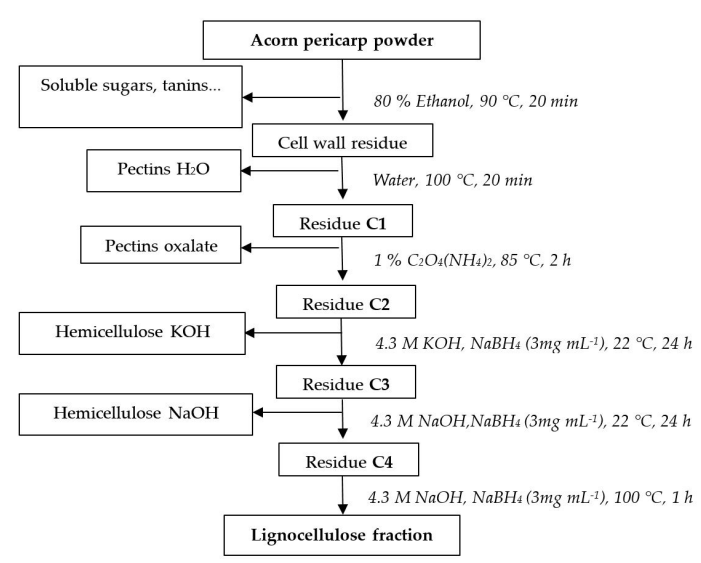

Figure 1. Extraction and isolation of cell wall polysaccharides.

\subsection{Qualitative analysis by gas liquid chromatography}

The monosaccharide composition of the extracted fractions was determined after methanolysis $(\mathrm{MeOH} / \mathrm{HCl} 1 \mathrm{M}, 24 \mathrm{~h}$, $80^{\circ} \mathrm{C}$ ) by gas-liquid chromatography of pertrimethylsilylated methylglycosides as previously described by Hachem et al. ${ }^{[7]}$.

\subsection{Fourier-transform Infrared spectroscopy (FT-IR)}

The different fractions from the acorn pericarps of Q. suber and Q. ilex were compressed into $\mathrm{KBr}$ pellets. The FTIR spectra of these pellets were obtained using a Cary 600 FTIR spectrophotometer (Agilent Technologies, Santa Clara, CA, USA) over the $400-4000 \mathrm{~cm}^{-1}$ range.

\section{Results and Discussions}

\subsection{Polysaccharide yields at each extraction step}

The freeze-dried cell wall residue contained $82.11 \pm 2.54 \%$ and $88.93 \pm 2.30 \%$ of the dry mass of the $Q$. suber and $Q$. ilex pericarp, respectively (Table 1 ). The lignocellulosic fraction comprised the main part, representing $37.19 \pm 8.63 \%$ and $48.95 \pm 8.51 \%$, respectively. The $\mathrm{KOH}$ and $\mathrm{NaOH}$ hemicellulose extracts represented $10.16 \pm 1.24 \%$ and $3.40 \pm 1.05 \%$ of the $Q$. suber cell wall residue, respectively, whereas these same hemicellulose fractions from $Q$. ilex represented $7.38 \pm 1.67 \%$, and $4.81 \pm 0.64 \%$, respectively. The hot water pectin extract of $Q$. suber and Q. ilex represented $6.47 \pm 3.04 \%$ and $3.88 \pm 0.78 \%$ of the cell wall residues and was composed of $9.6 \%$ and $20 \%$ uronic acid respectively. While ammonium oxalate pectin extracts of both species $(4.19 \pm 1.73 \%, 2.61 \pm 1.61 \%)$ contained more uronic acid than hot water extracts $(68.5 \%$ and $39.3 \%$ ). This difference may be the result of different environmental conditions and/or genetic factors that can affect the cell wall structure and also affect the levels of its various components ${ }^{[11]}$.

Comparing the composition of the two cell walls, it can be seen that the $Q$. ilex acorn pericarp appears to contain much more lignocellulose, but less pectin and hemicellulose polysaccharides, than $Q$. suber. This difference could be due to different environmental conditions and/or genetic factors, since these two distinct species of Quercus have different provenances; Saïda belongs to the high plateau, while Oran is situated on the Northwestern Mediterranean

Table 1.Yields of differentially extracted fractions prepared from Q. suber and Q.ilex acorn pericarps.

\begin{tabular}{|c|c|c|c|c|}
\hline \multirow{2}{*}{ Fractions } & \multicolumn{2}{|c|}{ Q. suber } & \multicolumn{2}{|c|}{ Q. ilex } \\
\hline & Extraction yield $(\%)^{* * *}$ & Uronic acid (\%) & Extraction yield $(\%)^{* * *}$ & Uronic acid (\%) \\
\hline Cell wall residue* & $82.11 \pm 2.54$ & $\mathrm{Nd}$ & $88.93 \pm 2.30$ & $\mathrm{Nd}$ \\
\hline Pectins $\mathrm{H}_{2} \mathrm{O}^{* *}$ & $6.47 \pm 3.04$ & 9.6 & $3.88 \pm 0.78$ & 20 \\
\hline Pectins oxalate ${ }^{* *}$ & $4.19 \pm 1.73$ & 68.5 & $2.61 \pm 1.61$ & 39.3 \\
\hline Hemicellulosic KOH** & $10.16 \pm 1.24$ & 19.6 & $7.38 \pm 1.67$ & 8 \\
\hline Hemicellulosic $\mathrm{NaOH}^{* *}$ & $3.40 \pm 1.05$ & 10.6 & $4.81 \pm 0.64$ & 10.2 \\
\hline Lignocellulosic fraction ${ }^{* *}$ & $37.19 \pm 8.63$ & $\mathrm{Nd}$ & $48.95 \pm 8.51$ & $\mathrm{Nd}$ \\
\hline
\end{tabular}

*Percentage of $15 \mathrm{~g}$ starting dry weight of pericarp powder; **\% Weight of cell wall residue, Nd: not detected; ***values are means \pm standard deviation of three samples. 
coast of Algeria. Numerous studies have shown that many abiotic and biotic factors, such as geographic location, soil salinity, light intensity, levels of water nutrition, plant species, time of harvest, and stage of life cycle can cause changes in cell wall structure and can significantly affect the levels of various cell wall components ${ }^{[11,12]}$.

\subsection{Monosaccharide composition of cell walls}

The amounts of pectins extracted with hot water or ammonium oxalate confirmed the high levels of pectin (Table 2), in agreement with the high levels of galacturonic acid (20.6 - 46.8\%). Rhamnose levels in the pectin extracts ranged from $5.2 \%$ to $8.3 \%$, suggesting that these fractions also contain rhamnogalacturonans that can be substituted with arabinan, galactan, and/or arabinogalactan side chains. The detection of fucose in pectins extracted from $Q$. ilex pericarps suggests the presence of rhamnogalactoronan II. Moreover, high levels of glucuronic acid in the pectins extracted with hot water from $Q$. ilex pericarps $(19.1 \%)$ suggest differences in the pectic components between the two species. According to Alba and Kontogiorgos ${ }^{[13]}$, the diversity of pectin structures depends on the botanical source, plant ripening stage, and extraction procedure as well. Hemicelluloses extracted with $\mathrm{KOH}$ or $\mathrm{NaOH}$ were found to be rich in xylose (Table 2), suggesting the presence of xylans. The Ara/Xyl ratio is interesting because it allows to compare the degrees of substitution of the polymer. In the fraction extracted with $\mathrm{KOH}$ this ratio is 0.37 , and 0.59 in $Q$. ilex and $Q$. suber pericarps respectively, compared to
0.40 and 0.42 for the fraction extracted with $\mathrm{NaOH}$. This suggests that the main xylan chain of $Q$. suber pericarps is more substituted than that of $Q$. ilex. The results obtained also show that the pericarps of both species contain xylans with significant degrees of substitution, compared to the results obtained by Habibi et al. ${ }^{[14,15]}$ with the seed pericarps of Opuntia ficus-indica and Argania spinosa. In the case of arabinoxylans, a low Ara / Xyl ratio corresponds to a low degree of polymer branching, making it less water soluble, while water soluble arabinoxylans are characterized by a higher Ara / Xyl ratio ${ }^{[16,17]}$. However, the presence of arabinoglucuronoxylans in the fraction extracted with $\mathrm{KOH}$ cannot be excluded given the presence of glucuronic acid (2.4 to $2.7 \%)$. Glucose (5.5 to $15.2 \%$ ) was also found, suggesting the presence of hemicelluloses of the xyloglucan type. According to Hu et al. ${ }^{[18]}$, xyloglucans are the predominant family of hemicelluloses and are mainly found in dicotyledons, but at lower levels in monocotyledons. The results obtained in our study are consistent with previous studies on the same tissues ${ }^{[19]}$.

\subsection{FT-IR spectra}

FT-IR spectra of pectins and hemicelluloses are presented in Figures 2 and 3. The large intense band between 3200 and $3500 \mathrm{~cm}^{-1}$ can be attributed to the elongation vibration of hydroxyl groups $(-\mathrm{OH})^{[20]}$. Small vibration bands indicating $\mathrm{C}-\mathrm{H}$ bonds were observed between 2800 and $3000 \mathrm{~cm}^{-1}$. Other signals at 1746 and $1756-1760 \mathrm{~cm}^{-1}$ suggest the presence of acetyl groups in pectic residues ${ }^{[21]}$. Absorption bands around 1600 and $1400 \mathrm{~cm}^{-1}$ can be attributed to carboxylate

Table 2. Monosaccharide composition of acorn pericarps from $Q$. suber, and $Q$. ilex assessed by gas liquid chromatography.

\begin{tabular}{|c|c|c|c|c|c|c|c|c|c|c|}
\hline & \multirow{2}{*}{ Species } & \multicolumn{9}{|c|}{ Monosaccharide composition (\%mol) } \\
\hline & & Ara & Rha & Fuc & Xyl & Gal A & Man & Gal & Glc & Glc A \\
\hline \multirow[t]{2}{*}{ Pectins $\mathrm{H}_{2} \mathrm{O}$} & Q.ilex & 16.1 & 6.9 & 1.5 & 4.5 & 24.3 & 2.1 & 11 & 14.5 & 19.1 \\
\hline & Q.suber & 36.9 & 8.3 & $\mathrm{Nd}$ & 3.1 & 20.6 & 0.8 & 5.9 & 21.5 & 2.9 \\
\hline \multirow[t]{2}{*}{ Pectins Oxalate } & Q.ilex & 13 & 5.2 & 0.9 & 3.5 & 46.8 & 5.6 & 12.1 & 4.4 & 8.5 \\
\hline & Q.suber & 18.6 & 7.2 & $\mathrm{Nd}$ & 1.6 & 23.5 & 1.7 & 11 & 24.3 & 12 \\
\hline \multirow[t]{2}{*}{ Hemicelluloses КОН } & Q.ilex & 18.5 & 4.8 & $\mathrm{Nd}$ & 49.4 & 8.5 & $\mathrm{Nd}$ & 9.8 & 6.3 & 2.7 \\
\hline & Q.suber & 21.9 & 5.8 & $\mathrm{Nd}$ & 36.7 & 8.6 & $\mathrm{Nd}$ & 9.4 & 15.2 & 2.4 \\
\hline \multirow[t]{2}{*}{ Hemicelluloses $\mathrm{NaOH}$} & Q.ilex & 18.3 & 4.7 & $\mathrm{Nd}$ & 45.7 & 13.8 & 1.4 & 9.5 & 6.5 & $\mathrm{Nd}$ \\
\hline & Q.suber & 20.5 & 6.2 & $\mathrm{Nd}$ & 48.5 & 13 & $\mathrm{Nd}$ & 6.3 & 5.5 & $\mathrm{Nd}$ \\
\hline
\end{tabular}

Ara: arabinose; Rha: rhamnose; Fuc: fucose; Xyl: xylose; Gal A: galacturonic acid; Man: mannose; Gal: galactose; Glc: glucose; Glc A: glucuronic acid; Nd: not detected.

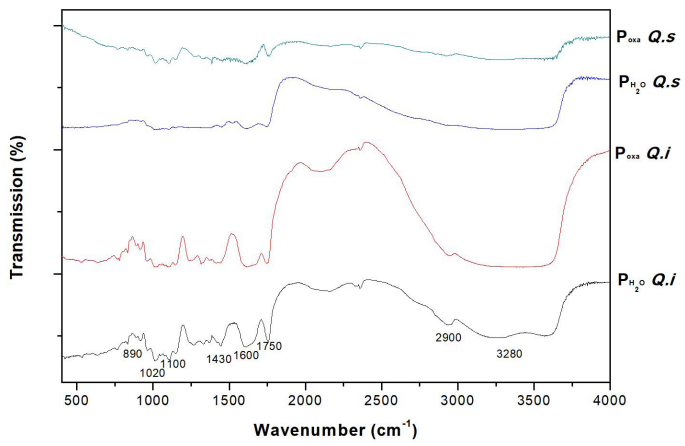

Figure 2. Infrared spectrum of the different pectin extracts; $\left(\mathrm{P}_{\mathrm{H} 2 \mathrm{O}}\right)$ : pectins extracted with hot water. $\left(\mathrm{P}_{\text {oxa }}\right)$ : pectins extracted with ammonium oxalate.(Q.s): Q. suber. (Q.i):Q. ilex.

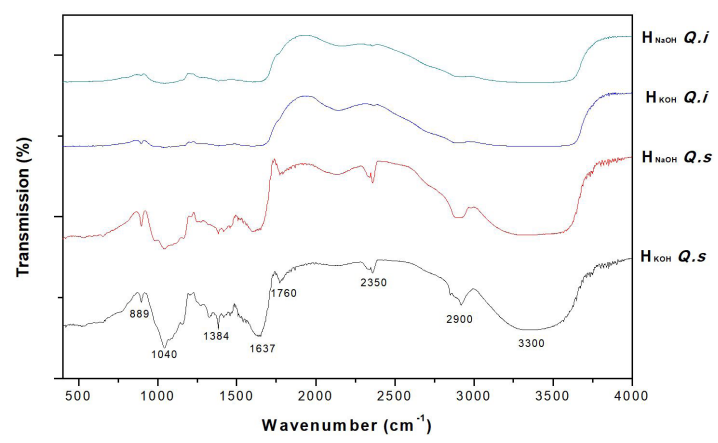

Figure 3. Infrared spectrum of different hemicellulose extracts; $\mathrm{H}_{\mathrm{NaOH}}$ : hemicelluloses extracted with $\mathrm{NaOH} . \mathrm{H}_{\mathrm{KOH}}$ : hemicelluloses extracted with KOH. (Q.s): Q. suber. (Q.i):Q. ilex. 
groups $\left(\mathrm{COO}^{-}\right)$. The large band at 1610 to $1637 \mathrm{~cm}^{-1}$ and the band near $1430 \mathrm{~cm}^{-1}$ were attributed to asymmetric and symmetric stretching of $\mathrm{C}=\mathrm{O}$, respectively ${ }^{[22]}$. Finally, the bands observed between 890 and $1200 \mathrm{~cm}^{-1}$ are specific of the vibrations of the $\mathrm{C}-\mathrm{O}-\mathrm{C}$ and $\mathrm{C}-\mathrm{O}-\mathrm{H}$ bonds present in polysaccharide structures ${ }^{[23]}$.

\section{Conclusions}

The results reported in this paper reveal that the cell wall of acorn pericarps from two Quercus species could be potential sources of bioactive constituents, mainly polysaccharides (pectins, hemicelluloses, celluloses) and lignin. These include xylans, xyloglucan type hemicelluloses, and homogalacturonan and rhamnogalacturonan pectins. These constituents are non-toxic, biocompatible, and biodegradable and hold a high potential for their broad application in food or for their pharmacological effects, which have yet to be exploited.

\section{Acknowledgements}

The authors acknowledge Pr. Vincent Sol, head of the PEIRENE laboratory (EA 7500 - France) for his warm and friendly welcome, and Dr. Michel Guilloton for his help in manuscript editing.

\section{References}

1. Sarir, R., \& Benmahioul, B. (2017). Etude comparative de la croissance végétative et du développement de jeunes semis de trois espèces de chênes (chêne vert, chêne liège et chêne zéen) cultivés en pépinière. Agriculture and Forestry Journal, 1, $42-48$.

2. Charef, M., Yousfi, M., Saidi, M., \& Stocker,P. (2008). Determination of the fatty acid composition of acorn (Quercus), Pistacia lentiscus seeds growing in Algeria. Journal of the American Oil Chemists' Society, 85(10), 921-924. http://dx.doi.org/10.1007/s11746-0081283-1.

3. Yang, J., Tu, J., Liu, H., Wen, L., Jiang, Y., \& Yang, B. (2019). Identification of an immunostimulatory polysaccharide in banana. Food Chemistry, 277, 46-53. http://dx.doi.org/10.1016/j. foodchem.2018.10.043. PMid:30502171.

4. Ramawat, K. G., \& Mérillon, J. M. (2015). Polysaccharides. New York: Springer International Publishing. http://dx.doi. org/10.1007/978-3-319-16298-0.

5. Tadayoni, M., Sheikh-Zeinoddin, M., \& Soleimanian-Zad, S. (2015). Isolation of bioactive polysaccharide from acorn and evaluation of its functional properties. International Journal of Biological Macromolecules, 72, 179-184. http://dx.doi.org/10.1016/j. ijbiomac.2014.08.015. PMid:25159883.

6. Vinha, A. F., Costa, A. S. G., Barreira, J. C. M., Pacheco, R., \& Oliveira, M. B. P. P. (2016). Chemical and antioxidant profiles of acorn tissues from Quercus spp.: potential as new industrial raw materials. Industrial Crops and Products, 94, 143-151. http:// dx.doi.org/10.1016/j.indcrop.2016.08.027.

7. Hachem, K., Faugeron, C., Kaid-Harche, M., \& Gloaguen, V. (2016). Structural investigation of cell wall xylan polysaccharides from the leaves of algerian Argania spinosa. Molecules (Basel, Switzerland), 21(11), 1587. http://dx.doi.org/10.3390/molecules21111587. PMid:27879638.

8. DuBois, M., Gilles, K. A., Hamilton, J. K., Rebers, P. A., \& Smith, F. (1956). Colorimetric method for determination of sugars and related substances. Analytical Chemistry, 28(3), 350-356. http:// dx.doi.org/10.1021/ac60111a017.

9. Blumenkrantz, N., \& Asboe-Hansen, G. (1973). New method for quantitative determination of uronic acids. Analytical Biochemistry,
54(2), 484-489. http://dx.doi.org/10.1016/0003-2697(73)90377-1. PMid:4269305.

10. Montreuil, J., Spik, G., Chosson, A., Segard, E., \& Scheppler, N. (1963). Methods of study of glycoproteins. Journal de Pharmacie de Belgique, 18, 529-546. PMid:14096752.

11. Stitt, M., \& Zeeman, S. C. (2012). Starch turnover: pathways, regulation and role in growth. Current Opinion in Plant Biology, 15(3), 282-292. http://dx.doi.org/10.1016/j.pbi.2012.03.016. PMid:22541711.

12. Dawczynski, C., Schubert, R., \& Jahreis, G. (2007). Amino acids, fatty acids, and dietary fibre in edible seaweed products. Food Chemistry, 103(3), 891-899. http://dx.doi.org/10.1016/j. foodchem.2006.09.041.

13. Alba, K., \& Kontogiorgos, V. (2017). Pectin at the oil-water interface: relationship of molecular composition and structure to functionality. Food Hydrocolloids, 68, 211-218. http://dx.doi. org/10.1016/j.foodhyd.2016.07.026.

14. Habibi, Y., Heux, L., Mahrouz, M., \& Vignon, M. R. (2008). Morphological and structural study of seed pericarp of Opuntia ficus-indica prickly pear fruits. Carbohydrate Polymers, 72(1), 102-112. http://dx.doi.org/10.1016/j.carbpol.2007.07.032.

15. Habibi, Y., \& Vignon, M. R. (2005). Isolation and characterization of xylans from seed pericarp of Argania spinosa fruit. Carbohydrate Research, 340(7), 1431-1436. http://dx.doi.org/10.1016/j. carres.2005.01.039. PMid:15854618.

16. Ebringerová, A., Hromádková, Z., Petráková, E., \& Hricovíni, M. (1990). Structural features of a water-soluble L-arabino-D-xylan from rye bran. Carbohydrate Research, 198(1), 57-66. http:// dx.doi.org/10.1016/0008-6215(90)84276-Z. PMid:2162256.

17. Xu, F., Sun, J. X., Geng, Z. C., Liu, C. F., Ren, J. L., Sun, R. C., Fowler, P., \& Baird, M. S. (2007). Comparative study of watersoluble and alkali-soluble hemicelluloses from perennial ryegrass leaves (Lolium peree). Carbohydrate Polymers, 67(1), 56-65. http://dx.doi.org/10.1016/j.carbpol.2006.04.014.

18. Hu, R., Xu, Y., Yu, C., He, K., Tang, Q., Jia, C., He, G., Wang, X., Kong, Y., \& Zhou, G. (2017). Transcriptome analysis of genes involved in secondary cell wall biosynthesis in developing internodes of Miscanthus lutarioriparius. Scientific Reports, 7(1), 9034. http:// dx.doi.org/10.1038/s41598-017-08690-8. PMid:28831170.

19. Yang, B., Jiang, Y., Zhao, M., Chen, F., Wang, R., Chen, Y., \& Zhang, D. (2009). Structural characterisation of polysaccharides purified from longan (Dimocarpus longan Lour.) fruit pericarp. Food Chemistry, 115(2), 609-614. http://dx.doi.org/10.1016/j. foodchem.2008.12.082.

20. Fernando, I. P. S., Sanjeewa, K. K. A., Samarakoon, K. W., Lee, W. W., Kim, H.-S., Kim, E.-A., Gunasekara, U. K. D. S. S., Abeytunga, D. T. U., Nanayakkara, C., de Silva, E. D., Lee, H.-S., \& Jeon, Y.-J. (2017). FTIR characterization and antioxidant activity of water soluble crude polysaccharides of Sri Lankan marine algae. Algae - Korean Phycological Society, 32(1), 75-86. http://dx.doi. org/10.4490/algae.2017.32.12.1.

21. Brito, A. C. F., Silva, D. A., Paula, R. C. M., \& Feitosa, J. P. A. (2004). Sterculia striata exudate polysaccharide: characterization, rheological properties and comparison with Sterculia urens (karaya) polysaccharide. Polymer International, 53(8), 1025-1032. http:// dx.doi.org/10.1002/pi.1468.

22. Pasandide, B., Khodaiyan, F., Mousavi, Z. E., \& Hosseini, S. S. (2017). Optimization of aqueous pectin extraction from Citrus medica peel. Carbohydrate Polymers, 178, 27-33. http://dx.doi. org/10.1016/j.carbpol.2017.08.098. PMid:29050593.

23. Morais, E. S., Mendonça, P. V., Coelho, J. F. J., Freire, M. G., Freire, C. S. R., Coutinho, J. A. P., \& Silvestre, A. J. D. (2018). Deep eutectic solvent aqueous solutions as efficient media for the solubilization of hardwood xylans. ChemSusChem, 11(4), 753-762. http://dx.doi.org/10.1002/cssc.201702007. PMid:29345423. 